\title{
Polymorphisms of candidate genes associated with meat quality and disease resistance in indigenous and exotic pig breeds of Vietnam
}

\author{
Ng.V. Cuong ${ }^{1 \#}$, Ng.T. Thu' ${ }^{1}$, T.T. Thoa ${ }^{1}$, T.X. Hoan ${ }^{2}$, Ng.T. Thuy ${ }^{1}$ \& Ng.T.D. Thuy ${ }^{1}$ \\ ${ }^{1}$ Institute of Biotechnology, Vietnam Academy of Science and Technology, Hanoi, Vietnam \\ ${ }^{2}$ National Institute of Animal Husbandry, Ministry of Agriculture and Rural Development, \\ Hanoi, Vietnam
Copyright resides with the authors in terms of the Creative Commons Attribution 2.5 South African Licence.
See: http://creativecommons.org/licenses/by/2.5/za
Condition of use: The user may copy, distribute, transmit and adapt the work, but must recognise the authors and the South African Journal of Animal Science.

\begin{abstract}
The objectives of this study were to analyse genotype distribution and sequence variations of candidate genes putatively associated with meat quality and disease resistance in exotic and indigenous Vietnamese pig breeds. For this purpose, 340 pigs from four indigenous and two exotic breeds were included in the analysis of the polymorphisms of the heart fatty-acid-binding protein $(H-F A B P)$, alpha 1 fucosyltransferase (FUT1), and bactericidal/permeability-increasing protein (BPI) genes by the sequencing and PCR-RFLP methods. For $H$-FABP, 17 single nucleotide polymorphisms (SNPs) were detected in indigenous pig breeds by direct sequencing of a fragment at intron 2 of the $H$-FABP gene. The mutation T1556C created a new restriction site for the enzyme $M s p \mathrm{I}$, which gave rise to new allelic variants in three indigenous pig breeds. In indigenous breeds, the frequency of the favourable alleles $a$ and $d$ at $M s p \mathrm{I}$ and Hae III sites of the H-FABP gene were low. Meanwhile, the frequency of the $d$ allele at the HaeIII site in exotic breeds was significantly higher than those of indigenous pig breeds. No mutation was found in the RFLP-fragment of the FUT1 gene of four indigenous pig breeds by sequencing, while in the BPI gene two mutations were detected in the Tap Na breed. The resistant alleles of the FUTI and BPI genes in the exotic breeds were significantly higher than those of indigenous pig breeds. Among the indigenous pig breeds, the Tap Na breed possessed a higher frequency of the resistant allele $G$ of BPI gene than the remaining breeds. The T1556C mutation at $H-F A B P$ may be important for the genetic improvement of intramuscular fat content and breed. Tap Na may be a source of resistant alleles for local ecologies.
\end{abstract}

Keywords: $H$-FABP gene, FUT1 gene, BPI gene, IMF, PCR-RFLP

\#Corresponding author: cuong_ibt@yahoo.com

\section{Introduction}

In recent decades, the aim of pig production in Vietnam has been directed at increasing the lean percentage of carcass and high-growth performance by making use of heterosis, mainly between indigenous and imported breeds such as the Landrace, Yorkshire and Large White (Molenat \& Thong, 1991). This effort has augmented the lean meat proportion and high-growth rate in the Vietnamese pig herd. However, it has also resulted in a decrease in some economically important traits such as adaptation to the indigenous ecologies, meat quality (pork becomes tougher and less flavourful) and disease resistance (Hai, 1996). The estimation of the frequency of genetic polymorphism in different pig breeds allows identification of both males and females carrying beneficial alleles early in life, thereby improving accuracy of selection, reducing the generation interval and accelerating the rate of genetic improvement of the trait.

Intramuscular fat (IMF) content is a major determinant of pork quality that determines the dietetic value and taste of pork (Janss et al., 1999). A higher IMF content has a favourful effect on the juiciness, palatability and tenderness of meat (Eikelenboom et al., 1996). The IMF deposition is a complicated process and is affected by genetic, physiological and biochemical factors. With respect to genetic factors, 4 to 13 
quantitative trait loci (QTLs) for IMF content have been identified in different pig populations (Gao \& Zhao, 2009). These QTLs for IMF were found on 11 chromosomes (PigQTLdb, http://www.genome.iastate.edu/cgi-bin/QTLdb/SS/index). In addition to QTL studies, many candidate gene polymorphisms have been analysed in terms of their associations with pig fatness. Among them, a confirmed effect on pig fatness was found for a well-known polymorphism of the heart fatty-acid-binding protein $(H-F A B P)$ gene (Gerbens et al., 1999; 2000). Heart fatty-acid-binding protein plays an important role in the transportation of intracellular fatty acids, thereby affecting the intramuscular fat content (Cameron \& Enser, 1991; Veerkamp et al., 1991). Three restriction enzymes (HinfI, HaeIII and MspI) that cut loci of H-FABP gene were identified as RFLP markers for IMF in pigs. In analysing the effects of the genotypes of $H$-FABP gene on IMF content, it has been found that the IMF content ordered by $H-F A B P$ were $d d>D d>D D$ and $a a>A a>A A$ (Gerbens et al., 2001). However, polymorphisms in the $H$-FABP gene in Vietnamese indigenous pig breeds and the association of IMF with different $H-F A B P$ genotypes have not been studied well.

Alpha fucosyltransferase (FUT1, FUT2) genes on porcine chromosome 6q11 have been identified and are closely linked to the blood group inhibitor (S) and Escherichia coli F18 receptor (ECF18R) loci. Vögeli et al. (1996) and Meijerink et al. (1997) all found a polymorphism that is closely linked to ECF18R in some exotic pigs. It is clear that FUT1 and FUT2 loci are associated with E. coli F18 adhesion resistant animals in these breeds. The research confirmed that a variation in the alpha 1 fucosyltransferase (FUT1) gene is the causative mutation for adhesion-resistant animals (Michaels et al., 1994; Bao et al., 2008). In addition to the F18-resistance marker, a marker for $E$. coli K88 has been identified (Michaels et al., 1994). Recently the first E. coli F18 resistant pig lines have been introduced by the PIC company through the use of genetic markers. The bactericidal/permeability-increasing protein (BPI) gene encodes BPI protein, which is a neutrophil granular pattern recognition molecule and has bactericidal activity on gram-negative bacteria, for example Salmonella (Elsbach \& Weiss, 1998). In newborns, a deficiency in BPI protein correlates with decreased antibacterial activity (Levy et al., 1999). Hollings \& Gray, (1994) reported the presence of a restriction fragment length polymorphism at BPI gene, which was detected by southern hybridization. Another polymorphism, detected by Pst digestion of a large PCR product, was reported for BPI gene (Hubacek et al., 2001). With the aims of developing genetic markers for meat quality, disease resistance and of further research on the characteristics of indigenous pig breeds, a DNA fragment of $H-F A B P, F U T 1$ and $B P I$ genes was sequenced and genotyped in six pig breeds in Vietnam.

\section{Materials and Methods}

Samples were collected from four Vietnamese indigenous pig breeds and two introduced breeds, namely Vietnamese Yorkshire and Landrace. Meo pigs (ME) are kept mainly by ethnic Thai and H'mong people in north and north west Vietnam. The Muong Khuong (MK) pig is kept by H'mong farmers in the mountainous areas of north Vietnam in particular. This pig is planned to be preserved mainly as a sow line for crossbreeding. The Tap $\mathrm{Na}(\mathrm{TN})$ has been found in Cao Bang province, kept under low-input conditions. It is well adapted to the ecological conditions in which it is kept. The Tap Na is said to be resistant to certain diseases, and to have tasty meat. The number of Tap Na pigs is decreasing, however, and it is at high risk of extinction (Duc et al., 2004). Mong Cai (MC) is the major indigenous breed in north and central Vietnam. It originated in the Red River delta, was used commercially and was kept at a station. The Mong Cai is adapted to poor-quality feed. In the large-frame type, it is said to have higher lean meat and growth rates. The Mong Cai was frequently used to improve indigenous breeds with lower performance. Vietnamese Yorkshire (YV) was introduced to Vietnam in 1936 and Vietnamese Landrace (LV) was imported in 1994. Exotic breeds are less adapted to the local environment and husbandry conditions than native breeds and perform below their genetic potential (Huy et al., 1996; Thien et al., 1996).

Blood samples were collected from the jugular veins of live animals. Blood was collected in test tubes containing an anticoagulant solution. Muscle tissue samples were taken from the pigs' ears. A total of 340 pigs from four indigenous breeds and two exotic breeds were included in the analysis. Samples from sows of MC $(n=46)$, YV $(n=52)$ and LV $(n=54)$ were collected at two breeding stations in Hanoi and Lao Cai province. For ME $(n=47)$, MK $(n=91)$ and $T N(n=50)$, approximately equal numbers of males and females were included.

Genomic DNA from blood and muscle tissue was isolated according to standard protocols (Sambrook et al., 1999). For amplification of the target DNA sequence involving a potential polymorphic site, the polymerase chain reaction (PCR) was used. Based on the published nucleotide sequence information of the 
$H-F A B P, F U T 1$ and $B P I$ genes, the following primers were used to amplify the target DNA sequences: primer $H$-FABP, forward primer 5'-ATT GCC TTC GGT GTG TTT GAG-3' and reverse primer 5'-TCA GGA ATG GGA GTT ATT GG-3' (GenBank accession No:Y16180); primer FUT1, forward primer 5'-CCA ACG CCT CCG ATT CCT GT-3' and reverse primer 5'-GTG CAT GGC AGG CTG GAT GA-3' (GenBank accession No: NM_214068.2); primer BPI, forward primer 5'-GGT GGC AAC TTT GAC CTG AG-3' and reverse primer 5'-CAT CGG AGG TCT CTG GAC AAG-3' (GenBank accession No: AF_252874.1). PCR amplifications were performed in a $25 \mu \mathrm{L}$ reaction solution and the standard PCR conditions for each candidate gene are presented in Table 1 . The PCR thermal cycles were as follows: An initial 4 min at $94{ }^{\circ} \mathrm{C}$, followed by 35 cycles of denaturation at $94{ }^{\circ} \mathrm{C}(35 \mathrm{sec})$; annealing at $57^{\circ} \mathrm{C}(50 \mathrm{sec})$ for $H-F A B P$, $(40 \mathrm{sec})$ for FUT1 and $55^{\circ} \mathrm{C}(45 \mathrm{sec})$ for $B P I$; and polymerization at $72{ }^{\circ} \mathrm{C}(45 \mathrm{sec})$. The final cycle was concluded by an extension interval of $7 \mathrm{~min}$ at $72{ }^{\circ} \mathrm{C}$ and the PCR products were stored at $4{ }^{\circ} \mathrm{C}$.

Table 1 PCR components for amplifying the $H-F A B P, F U T 1$ and BPI gene

\begin{tabular}{|c|c|c|c|}
\hline \multirow{2}{*}{ Component } & \multicolumn{3}{|c|}{$\begin{array}{l}\text { Volume of the components in each candidate gene } \\
(\mu \mathrm{L})\end{array}$} \\
\hline & $H-F A B P$ & FUT1 & $B P I$ \\
\hline $\mathrm{H}_{2} \mathrm{O}$ deionized & 17.2 & 17.7 & 18.35 \\
\hline Buffer 10x & 2.5 & 2.5 & 2.5 \\
\hline $\mathrm{MgCl}_{2} 25 \mathrm{mM}$ & 2.0 & 1.5 & 0.75 \\
\hline dNTPs $25 \mathrm{mM}$ & 0.2 & 0.2 & 0.2 \\
\hline Forward primer $5 \mathrm{pM}, 10 \mathrm{pM}$ & 1.0 & 1.0 & 1.0 \\
\hline Reverse primer $5 \mathrm{pM}, 10 \mathrm{pM}$ & 1.0 & 1.0 & 1.0 \\
\hline Taq $1 \mathrm{u} / \mu \mathrm{L}$ (Fermentas, Invitrogen) & 0.1 & 0.1 & 0.2 \\
\hline DNA template $50 \mathrm{ng} / \mu \mathrm{L}$ & 1.0 & 1.0 & 1.0 \\
\hline Total volume $(\mu \mathrm{L})$ & 25.0 & 25.0 & 25.0 \\
\hline
\end{tabular}

Fifteen $\mu \mathrm{L}$ of the PCR products of $H$-FABP, FUT1 and BPI were digested overnight at $37{ }^{\circ} \mathrm{C}$ by Hae III (6U), MspI (6U) for H-FABP, Hin6I (10U) for FUTI and AvaII (10U) for BPI. The digested products were separated by electrophoresis through a $2.5 \%$ agarose gel. The PCR products were purified with the QIAquick PCR Purification kits (QIAGEN). For each candidate gene, the DNA fragment from five individuals per breed was sequenced using an ABI PRISM ${ }^{\circledR} 3100$ Avant Genetic Analyzer. The sequences were aligned by Clustalx2, bioedit, and Mega 4.1 software. Restriction endonuclease DNA STARsites were detected by using primer premier 5.0 software (Lalitha, 2000).

Statistical analysis and frequencies of genotypes and alleles were estimated by direct counting in the six breeds under study. Differences between frequencies of genotypes and alleles were estimated by the t- test. Hardy-Weinberg equilibrium was tested by comparing expected and observed genotype frequencies using a chi-square test. If the observed and expected counts were not significantly different $(P>0.05)$, the population was in Hardy-Weinberg equilibrium. The expected heterozygosity $(\mathrm{He})$ was calculated according to Nei (1978).

$$
\mathrm{He}=1-\sum_{\mathrm{i}=1}^{\mathrm{k}} \mathrm{p}_{\mathrm{i}}^{2}
$$

where $\mathrm{p}_{\mathrm{i}}$ is the frequency of the $\mathrm{i}^{\text {th }}$ of $\mathrm{k}$ alleles.

Polymorphism information content (PIC) was calculated according to the formula: 


$$
P I C=1-\sum_{i=1}^{n} P_{i}^{2}-\sum_{i=1}^{n-1} \underset{j=i+1}{n} 2 P_{i}^{2} P_{j}^{2}
$$

Where:

$\mathrm{P}_{\mathrm{i}}=$ The frequency of allele $\mathrm{i}$

$\mathrm{j}=$ The allele $\mathrm{n}$ having codominance with allele $\mathrm{i}$

$\mathrm{n}=$ The number of individuals of one population

A population is said to be highly polymorphic if PIC $>0.5$ and low polymorphic if PIC $<0.25$ (Botstein et al., 1980).

\section{Results}

By sequencing an 816 bp fragment at intron 2 of $H$-FABP gene, 17 SNPs were found in four indigenous pig breeds, of which 14 were substitutions and three were insertions. The frequencies of mutation varied from $0.86 \%$ (7/816) for MC to $1.22 \%$ (10/816) for MK. The insertion mutation caused an increased RFLP fragment size of 821 bp in ME, MK, MC and 822 bp in TN. The T1556C mutation created a novel restriction site for the $M s p I$. These results corresponded well with the PCR-RFLP data. In the ME, MK and TN breeds, two MspI recognition sites were found in the RFLP fragments, while in two exotic and MC breeds only one MspI site was detected. The RFLP polymorphism of $H$-FABP gene was detected by the PCR-RFLP method using the restriction enzymes, MspI and HaeIII. Digestion of the PCR product with MspI produced four alleles $a, A, b$ and $B$. The $816 \mathrm{bp}$ fragment was defined as allele $a, 727$ and 89 bp as allele $A$, 660 and 156 bp as allele $b$, and 660, 89 and 67 bp as allele $B$. Genotyping 340 pigs from six breeds identified three alleles $a, A$ and $B$ (Figure 1A). Allele and genotype frequencies estimated at $M s p I$ loci of the $H$-FABP gene in six breeds are given in Table 2 (A). The results showed that the $M s p$ I polymorphic site of $H$-FABP gene was found in five of the breeds, but not in the MC. In indigenous pig breeds ME, MK and TN (which are maintained in their original environments), three alleles, $A, a$ and $B$, were identified with average frequencies of $0.95,0.002$ and 0.05 , respectively.

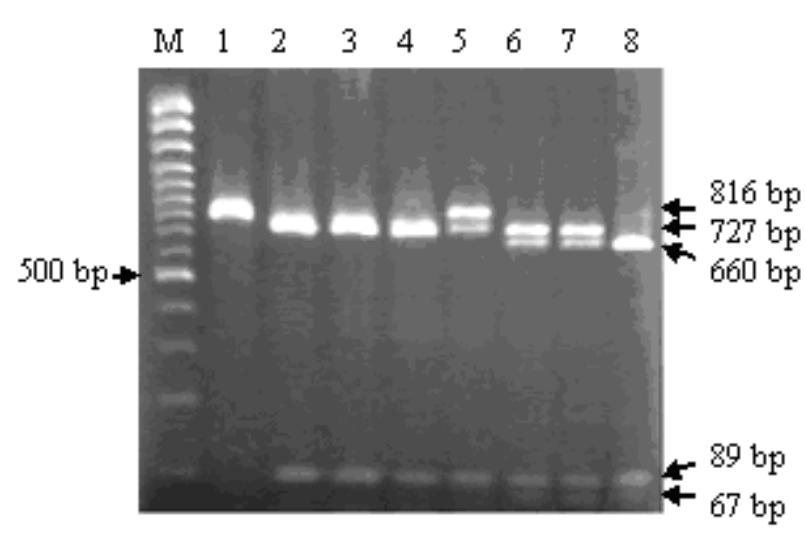

(A)

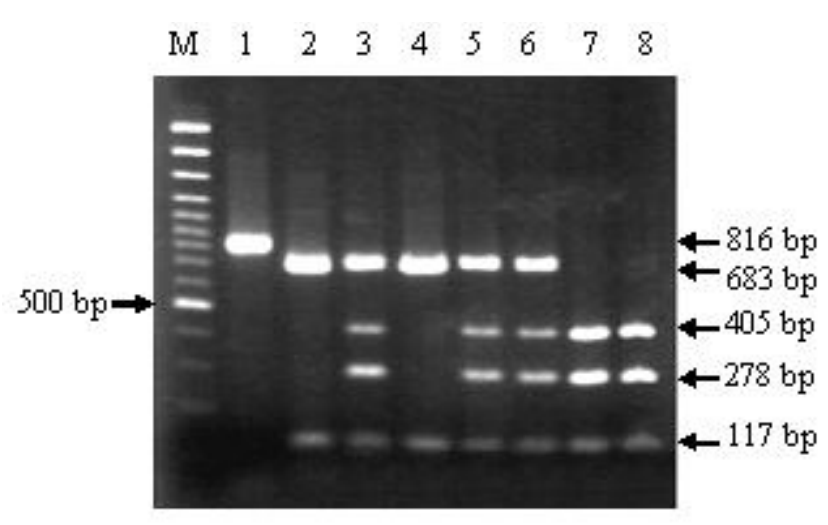

(B)

Figure 1 Polymorphism of the $H-F A B P$ gene in pigs

(A) MspI polymorphism of the $H-F A B P$ gene. The genetic variations of $H$-FABP gene were investigated by PCRRFLP. The digested PCR products with $M s p I$ generated a 816 bp fragment for allele $a$; two fragments of 727, 89 bp for allele $A$; two fragments of 660,156 bp for allele $b$; and three fragments of 660, 89, 67 bp for allele $B$. Lane M: standards for size determination. Lane 1: PCR product of 816 bp. Lane 2, 3, 4: genotype $A A$. Lane 5: genotype $A a$. Lane 6, 7: genotype $A B$. Lane 8: genotype $B B$.

(B) HaeIII polymorphism of the HFABP gene. The polymorphisms of $H$-FABP gene were investigated by PCR-RFLP using specific primers and the restriction enzyme HaeIII. Allele $D$ is a digested PCR product at two positions to create three fragments of 683, 117 and $16 \mathrm{bp}$. Allele $d$ is a digested PCR product at three positions to create four fragments of 405, 278, 117 and $16 \mathrm{bp}$. Lane M: standards for size determination. Lane 1: PCR product. Lane 2, 4: genotype $D D$. Lane 3, 5, 6: genotype $D d$. Lane 7, 8: genotype $d d$. 
In exotic breeds, $\mathrm{YV}$ and $\mathrm{LV}$, and indigenous breed $\mathrm{MC}$, which is kept at a breeding station, only two alleles (A and a) were found, with average frequencies of 0.97 and 0.03 . In all populations, $A$ was a major allele. The frequency of the favourable allele, $a$, did not differ much between the indigenous and exotic breeds. The PIC values at the MspI site were low in indigenous (0.09) and exotic (0.06) breeds. Except for the $\mathrm{MC}$ breed, the genotype frequencies at MspI loci were in Hardy-Weinberg equilibrium.

Table 2 Genotype, allele frequencies and heterozygosity of $H-F A B P$ gene in six pig breeds

(A) At MspI-RFLP site

\begin{tabular}{|c|c|c|c|c|c|c|c|c|c|c|c|}
\hline \multirow{2}{*}{ Breed $^{\mathrm{a}}$} & \multirow{2}{*}{$\begin{array}{l}\text { Sample } \\
\text { size (n) }\end{array}$} & \multicolumn{4}{|c|}{ Genotype frequencies (no. of pigs) ${ }^{b}$} & \multicolumn{3}{|c|}{ Allele frequencies } & \multirow{2}{*}{$\mathrm{He}^{\mathrm{c}}$} & \multirow{2}{*}{$\mathrm{PIC}^{\mathrm{d}}$} & \multirow{2}{*}{$\chi 2^{\mathrm{e}}$} \\
\hline & & $A A$ & $A a$ & $A B$ & $B B$ & $A$ & $a$ & $B$ & & & \\
\hline ME & 47 & $0.96(45)$ & $0.02(1)$ & $0.02(1)$ & $0.00(0)$ & 0.98 & 0.01 & 0.01 & 0.04 & 0.04 & $\mathrm{~ns}$ \\
\hline MK & 91 & $0.79(72)$ & $0.00(0)$ & $0.20(18)$ & $0.01(1)$ & 0.89 & 0.00 & 0.11 & 0.20 & 0.18 & $\mathrm{~ns}$ \\
\hline $\mathrm{TN}$ & 50 & $0.88(44)$ & $0.00(0)$ & $0.10(5)$ & $0.02(1)$ & 0.93 & 0.00 & 0.07 & 0.13 & 0.12 & $\mathrm{~ns}$ \\
\hline $\mathrm{MC}$ & 46 & $1.00(46)$ & $0.00(0)$ & $0.00(0)$ & $0.00(0)$ & 1.00 & 0.00 & 0.00 & 0.00 & 0.00 & - \\
\hline $\begin{array}{l}\text { Mean } \pm \\
\operatorname{IndB}^{f}\end{array}$ & & $\begin{array}{c}0.91 \\
\pm 0.09\end{array}$ & $\begin{array}{c}0.01 \\
\pm 0.01\end{array}$ & $\begin{array}{c}0.08 \\
\pm 0.09\end{array}$ & $\begin{array}{c}0.01 \\
\pm 0.00\end{array}$ & $\begin{array}{c}0.95 \\
\pm 0.05\end{array}$ & $\begin{array}{c}0.00 \\
\pm 0.01\end{array}$ & $\begin{array}{c}0.05 \\
\pm 0.05\end{array}$ & $\begin{array}{l}0.09 \\
\pm 0.09\end{array}$ & $\begin{array}{c}0.09 \\
\pm 0.08\end{array}$ & \\
\hline YV & 52 & 0.94 (49) & $0.06(3)$ & $0.00(0)$ & $0.00(0)$ & 0.97 & 0.03 & 0.00 & 0.06 & 0.05 & ns \\
\hline LV & 54 & $0.93(50)$ & $0.07(4)$ & $0.00(0)$ & $0.00(0)$ & 0.96 & 0.04 & 0.00 & 0.07 & 0.07 & $\mathrm{~ns}$ \\
\hline $\begin{array}{l}\text { Mean } \pm \\
\text { ExoB }^{\mathrm{g}}\end{array}$ & & $\begin{array}{c}0.93 \\
\pm 0.01\end{array}$ & $\begin{array}{c}0.06 \\
\pm 0.01\end{array}$ & 0.00 & 0.00 & $\begin{array}{c}0.97 \\
\pm 0.01\end{array}$ & $\begin{array}{c}0.03 \\
\pm 0.01\end{array}$ & 0.00 & $\begin{array}{c}0.06 \\
\pm 0.01\end{array}$ & $\begin{array}{c}0.06 \\
\pm 0.01\end{array}$ & \\
\hline
\end{tabular}

(B) At HaeIII-RFLP site

\begin{tabular}{|c|c|c|c|c|c|c|c|c|c|}
\hline \multirow{2}{*}{ Breed $^{\mathrm{a}}$} & \multirow{2}{*}{$\begin{array}{l}\text { Sample } \\
\text { size (n) }\end{array}$} & \multicolumn{3}{|c|}{$\begin{array}{l}\text { Genotype frequencies } \\
\text { (no. of pigs) }^{b}\end{array}$} & \multicolumn{2}{|c|}{ Allele frequencies } & \multirow{2}{*}{$\mathrm{He}^{\mathrm{c}}$} & \multirow{2}{*}{$\mathrm{PIC}^{\mathrm{d}}$} & \multirow[t]{2}{*}{$\chi 2^{\mathrm{e}}$} \\
\hline & & $D D$ & $D d$ & $d d$ & $D$ & $d$ & & & \\
\hline ME & 47 & 0.94 (44) & $0.06(3)$ & 0.00 & 0.97 & 0.03 & 0.06 & 0.06 & ns \\
\hline MK & 91 & $0.96(87)$ & $0.04(2)$ & 0.00 & 0.98 & 0.02 & 0.04 & 0.04 & ns \\
\hline $\mathrm{TN}$ & 50 & $1.00(50)$ & $0.00(0)$ & 0.00 & 1.00 & 0.00 & 0.00 & 0.00 & - \\
\hline $\mathrm{MC}$ & 46 & $0.98(45)$ & $0.02(1)$ & 0.00 & 0.99 & 0.01 & 0.02 & 0.02 & ns \\
\hline $\begin{array}{l}\text { Mean } \pm \\
\operatorname{IndB}^{f}\end{array}$ & & $\begin{array}{c}0.97 \\
\pm 0.03\end{array}$ & $\begin{array}{c}0.03 \\
\pm 0.03\end{array}$ & 0.00 & $\begin{array}{c}0.98 \\
\pm 0.01\end{array}$ & $\begin{array}{c}0.02 \\
\pm 0.01\end{array}$ & $\begin{array}{c}0.03 \\
\pm 0.03\end{array}$ & $\begin{array}{c}0.03 \\
\pm 0.02\end{array}$ & \\
\hline YV & 52 & $0.44(23)$ & $0.44(23)$ & $0.12(6)$ & 0.66 & 0.34 & 0.45 & 0.35 & \\
\hline LV & 54 & $0.22(12)$ & $0.39(21)$ & $0.39(21)$ & 0.42 & 0.58 & 0.49 & 0.37 & $\mathrm{~ns}$ \\
\hline $\begin{array}{l}\text { Mean } \pm \\
\text { ExoB }^{g}\end{array}$ & & $\begin{array}{c}0.33 \\
\pm 0.15\end{array}$ & $\begin{array}{c}0.41 \\
\pm 0.03\end{array}$ & $\begin{array}{c}0.25 \\
\pm 0.19\end{array}$ & $\begin{array}{c}0.54 \\
\pm 0.17\end{array}$ & $\begin{array}{c}0.46 \\
\pm 0.17\end{array}$ & $\begin{array}{c}0.47 \\
\pm 0.03\end{array}$ & $\begin{array}{c}0.36 \\
\pm 0.01\end{array}$ & ns \\
\hline
\end{tabular}

${ }^{a}$ Pig breeds: ME - Meo; MK - Muong Khuong; TN - Tap Na; MC - Mong Cai; YV - Vietnamese Yorkshire;

LV - Vietnamese Landrace.

${ }^{\mathrm{b}}$ Values in parentheses are the numbers of pigs found in each genotype.

${ }^{\mathrm{c}} \mathrm{He}$ - expected heterozygosity.

${ }^{\mathrm{d}} \mathrm{PIC}$ - polymorphism information content.

$\chi 2^{\mathrm{e}}$ - chi-square test; ns - not significant (the population was in HWE).

${ }_{\mathrm{t}}^{\mathrm{t}}$ Mean values of genotype, allele frequencies and heterozygosity in indigenous pig breeds.

${ }^{\mathrm{g}}$ Mean values of genotype, allele frequencies and heterozygosity in exotic pig breeds. 
The same 816 bp fragment had three HaeIII sites. When this segment of DNA is cut by HaeIII, four restriction fragments $(405,278,117$ and $16 \mathrm{bp})$ are produced. A polymorphism at the position $1811 \mathrm{bp}$ would result in the destruction of a HaeIII site, merging the $278 \mathrm{bp}$ and $405 \mathrm{bp}$ into a $683 \mathrm{bp}$ fragment. Allele $d$ was defined as the presence of the 405, 278, 117 and 16 bp fragments. Allele $D$ is a digested PCR product at two positions to create three fragments of 683, 117 and 16 bp (Figure 1B). Allele and genotype frequencies estimated at HaeIII loci are given in Table 2 (B). In local pig breeds, the homozygotes $D D$ were the most frequent, ranging from 0.94 in ME to 1.00 in TN. The homozygote $d d$ was not found in any indigenous pig breed. In exotic breeds, three genotypes $D D, D d$ and $d d$ were found with average frequencies of $0.33,0.41$ and 0.25 , respectively. The PIC value at HaeIII site in exotic breeds was higher $(P<0.01)$ than in indigenous pig breeds. Except for the TN breed, the genotype frequencies at HaeIII loci were in HardyWeinberg equilibrium.

The nucleotide sequence of the $161 \mathrm{bp}$ fragment at the open reading frame of FUT1 gene in four indigenous pig breeds showed 100\% identity with the reference sequence (NM_214068.2). An A359G mutation, which is recognized by Hin6I, was also identified in all tested pig breeds. Sequencing results corresponded well with the PCR-RFLP data. Hin6IRFLP formed two alleles, $A$ and $G$, in which allele $A$ was defined as the presence of undigested PCR products of $161 \mathrm{bp}$, while allele $G$ was defined as the presence of digested PCR products to create two fragments of 117 and 44 bp (Figure 2 A).

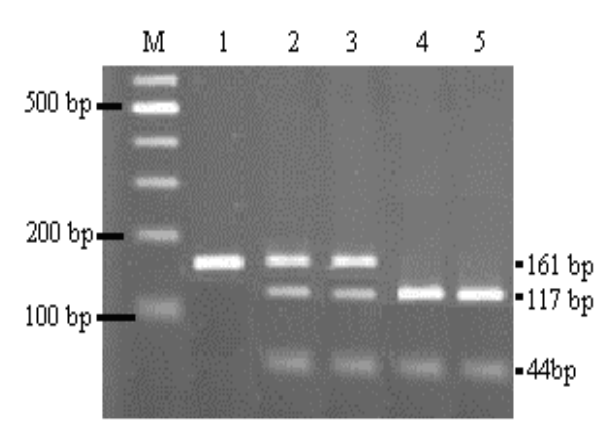

(A)

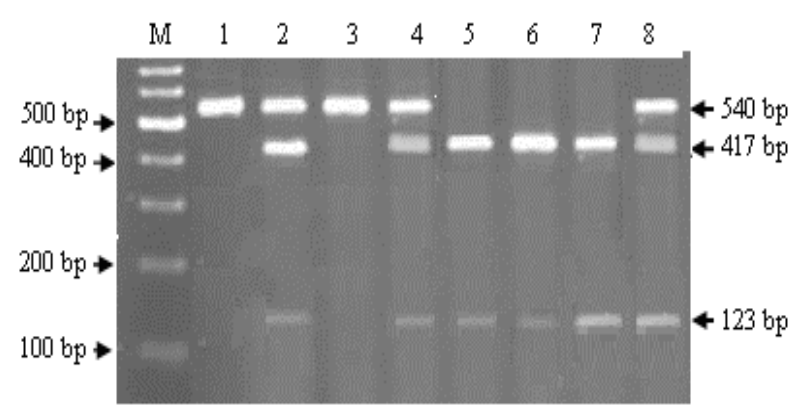

(B)

Figure 2 Polymorphism of the FUT1 and BPI genes in pigs

(A) Hin6I polymorphism of the FUT1 gene. The genetic variations of $F U T 1$ gene were investigated by PCR-RFLP. The digested PCR products with Hin6I generated a $161 \mathrm{bp}$ fragment for allele $A$ and 117, $44 \mathrm{bp}$ fragments for allele $G$. Lane M: standards for size determination. Lane 1: PCR product. Lane 2, 3: genotype $A G$. Lane 4, 5: genotype $G G$.

(B) AvaII polymorphism of the BPI gene. The polymorphisms of BPI gene were investigated by PCR-RFLP using specific primers and the restriction enzyme AvaII. Allele $A$ is a not digested PCR product of $540 \mathrm{bp}$, while allele $G$ is a digested PCR product to create two fragments of 417 and $123 \mathrm{bp}$. Lane M: standards for size determination. Lane 1, 3: genotype $A A$. Lane 5, 6, 7: genotype $G G$. Lane 2, 4, 8: genotype $A G$.

The Hin6I PCR-RFLP polymorphism of the FUT1 gene was investigated in a total of 333 pigs from four indigenous pig breeds and two exotic. Results showed that homozygote, $A A$, was present only in the exotic breeds with frequencies of 0.13 and 0.07 in $\mathrm{YV}$ and LV, respectively (Table 3A). The average frequencies of genotypes $A A, A G$ and $G G$ in the exotic breeds were $0.10,0.21$ and 0.68 , respectively. The indigenous pig breeds TN and MC possessed only the $G G$ genotype. The two other indigenous breeds, ME and MK, presented two susceptible genotypes, $G G$ and $A G$, with allele frequencies for $G$ of 0.98 and 0.96 , respectively. The expected heterozygosity of indigenous pig breeds was lower $(P<0.01)$ than those of exotic breeds and varied between 0.00 (TN, MC) and $0.08(\mathrm{MK})$, whereas values for the exotic breeds were 0.39 and 0.27 in YV and LV, respectively. The genotypes frequencies obtained in ME and MK breeds were in Hardy-Weinberg equilibrium.

The $540 \mathrm{bp}$ fragment of BPI gene in indigenous pig breeds was sequenced. The sequence comparison of the indigenous pig breeds with the references of GenBank sequence AF252874 revealed two substitution mutations at the positions $\mathrm{T} 69 \mathrm{G}, \mathrm{A} 409 \mathrm{G}$ in the TN breed. 
Table 3 Genotype, allele frequencies and heterozygosity of FUTI and BPI genes in six pig breeds

(A) Hin6I-RFLP of FUT1 gene

\begin{tabular}{|c|c|c|c|c|c|c|c|c|c|}
\hline \multirow[t]{2}{*}{ Breed $^{\mathrm{a}}$} & \multirow{2}{*}{$\begin{array}{l}\text { Sample } \\
\text { size (n) }\end{array}$} & \multicolumn{3}{|c|}{$\begin{array}{c}\text { Genotype frequencies } \\
\text { (no. of pigs) })^{\mathrm{b}}\end{array}$} & \multicolumn{2}{|c|}{ Allele frequencies } & \multirow[t]{2}{*}{$\mathrm{He}^{\mathrm{c}}$} & \multirow[t]{2}{*}{$\mathrm{PIC}^{\mathrm{d}}$} & \multirow[t]{2}{*}{$\chi^{2}$} \\
\hline & & $A A$ & $A G$ & $G G$ & $A$ & $G$ & & & \\
\hline ME & 42 & $0.00(0)$ & $0.05(2)$ & $0.95(40)$ & 0.02 & 0.98 & 0.05 & 0.05 & ns. \\
\hline MK & 91 & $0.00(0)$ & $0.09(8)$ & $0.91(83)$ & 0.04 & 0.96 & 0.08 & 0.08 & ns. \\
\hline $\mathrm{TN}$ & 48 & $0.00(0)$ & $0.00(0)$ & $1.00(48)$ & 0.00 & 1.00 & 0.00 & 0.00 & - \\
\hline $\mathrm{MC}$ & 46 & $0.00(0)$ & $0.00(0)$ & $1.00(46)$ & 0.00 & 1.00 & 0.00 & 0.00 & - \\
\hline $\begin{array}{l}\text { Mean } \pm \\
\operatorname{IndB}^{f}\end{array}$ & & $\begin{array}{l}0.00 \\
\pm 0.00\end{array}$ & $\begin{array}{c}0.04 \\
\pm 0.04\end{array}$ & $\begin{array}{c}0.96 \\
\pm 0.04\end{array}$ & $\begin{array}{c}0.02 \\
\pm 0.02\end{array}$ & $\begin{array}{c}0.98 \\
\pm 0.02\end{array}$ & $\begin{array}{c}0.03 \\
\pm 0.04\end{array}$ & $\begin{array}{c}0.03 \\
\pm 0.04\end{array}$ & \\
\hline YV & 52 & $0.13(7)$ & $0.27(14)$ & $0.60(31)$ & 0.27 & 0.73 & 0.39 & 0.32 & * \\
\hline LV & 54 & $0.07(4)$ & $0.17(9)$ & $0.76(41)$ & 0.16 & 0.84 & 0.27 & 0.23 & $* *$ \\
\hline $\begin{array}{l}\text { Mean } \pm \\
\text { ExoB }^{\mathrm{g}}\end{array}$ & & $\begin{array}{c}0.10 \\
\pm 0.03\end{array}$ & $\begin{array}{c}0.21 \\
\pm 0.07\end{array}$ & $\begin{array}{c}0.68 \\
\pm 0.11\end{array}$ & $\begin{array}{c}0.21 \\
\pm 0.07\end{array}$ & $\begin{array}{c}0.78 \\
\pm 0.07\end{array}$ & $\begin{array}{c}0.33 \\
\pm 0.09\end{array}$ & $\begin{array}{c}0.27 \\
\pm 0.06\end{array}$ & \\
\hline
\end{tabular}

(B) AvaII-RFLP of BPI gene

\begin{tabular}{|c|c|c|c|c|c|c|c|c|c|}
\hline \multirow{2}{*}{ Breed $^{a}$} & \multirow{2}{*}{$\begin{array}{l}\text { Sample } \\
\text { size }(n)\end{array}$} & \multicolumn{3}{|c|}{$\begin{array}{l}\text { Genotype frequencies } \\
\text { (no. of pigs) })^{\mathrm{b}}\end{array}$} & \multicolumn{2}{|c|}{$\begin{array}{c}\text { Allele } \\
\text { frequencies }\end{array}$} & \multirow{2}{*}{$\mathrm{He}^{\mathrm{c}}$} & \multirow{2}{*}{$\mathrm{PIC}^{\mathrm{d}}$} & \multirow[t]{2}{*}{$\chi 2^{\circ}$} \\
\hline & & $A A$ & $A G$ & $G G$ & $A$ & $G$ & & & \\
\hline ME & 42 & $0.17(7)$ & $0.33(14)$ & $0.50(21)$ & 0.33 & 0.66 & 0.44 & 0.35 & $\mathrm{~ns}$ \\
\hline MK & 91 & $0.20(18)$ & $0.30(27)$ & $0.50(46)$ & 0.35 & 0.65 & 0.45 & 0.35 & $* *$ \\
\hline $\mathrm{TN}$ & 48 & $0.06(3)$ & 0.27 (13) & $0.67(32)$ & 0.19 & 0.80 & 0.31 & 0.26 & $\mathrm{~ns}$ \\
\hline $\mathrm{MC}$ & 46 & 0.09 (4) & $0.48(22)$ & $0.43(20)$ & 0.33 & 0.67 & 0.44 & 0.34 & $\mathrm{~ns}$ \\
\hline $\begin{array}{l}\text { Mean } \pm \\
\operatorname{IndB}^{f}\end{array}$ & & $\begin{array}{l}0.13 \\
\pm 0.07\end{array}$ & $\begin{array}{c}0.34 \\
\pm 0.09\end{array}$ & $\begin{array}{c}0.52 \\
\pm 0.10\end{array}$ & $\begin{array}{c}0.30 \\
\pm 0.07\end{array}$ & $\begin{array}{c}0.70 \\
\pm 0.07\end{array}$ & $\begin{array}{c}0.42 \\
\pm 0.07\end{array}$ & $\begin{array}{c}0.33 \\
\pm 0.04\end{array}$ & \\
\hline YV & 52 & $0.00(0)$ & $0.00(0)$ & $1.00(52)$ & 0.00 & 1.00 & 0.00 & - & - \\
\hline LV & 54 & $0.00(0)$ & $0.00(0)$ & $1.00(54)$ & 0.00 & 1.00 & 0.00 & - & - \\
\hline $\begin{array}{l}\text { Mean } \pm \\
\text { ExoB }^{g}\end{array}$ & & $\begin{array}{l}0.00 \\
\pm 0.00\end{array}$ & $\begin{array}{c}0.00 \\
\pm 0.00\end{array}$ & $\begin{array}{c}1.00 \\
\pm 0.00\end{array}$ & $\begin{array}{c}0.00 \\
\pm 0.00\end{array}$ & $\begin{array}{c}1.00 \\
\pm 0.00\end{array}$ & $\begin{array}{c}0.00 \\
\pm 0.00\end{array}$ & & \\
\hline
\end{tabular}

${ }^{2}$ Pig breeds: ME - Meo; MK - Muong Khuong; TN - Tap Na; MC - Mong Cai; YV - Vietnamese Yorkshire;

LV - Vietnamese Landrace.

${ }^{\mathrm{b}}$ Values in parentheses are the numbers of pigs found in each genotype.

${ }^{c} \mathrm{He}$ - expected heterozygosity.

${ }^{\mathrm{d}} \mathrm{PIC}$ - polymorphism information content.

$\chi 2^{\mathrm{e}}$ - chi-square test; ns - not significant (the population was in HWE).

* significant at $P \leq 0.05 ; * *$ significant at $P \leq 0.01$ ).

${ }^{\mathrm{f}}$ Mean values of genotype, allele frequencies and heterozygosity in indigenous pig breeds.

${ }^{\mathrm{g}}$ Mean values of genotype, allele frequencies and heterozygosity in exotic pig breeds.

These mutations did not alter any known restriction site. RFLP genotyping of the BPI gene was investigated by using the restriction enzyme AvaII. Allele $A$ was defined as an undigested PCR product of $540 \mathrm{bp}$, while allele $G$ was a digested PCR product to create two fragments of 417 and 123 bp (Figure 2B). The results showed that the exotic pig breeds were monomorph and possessed only the genotype $G G$ (Table 
3B). All indigenous pig breeds were polymorph and possessed three genotypes. The favourable allele $G$ was detected with a frequency of $0.66,0.65,0.80$ and 0.67 in $\mathrm{ME}, \mathrm{MK}, \mathrm{TN}$ and $\mathrm{MC}$, respectively. The expected heterozygosity values varied between $0.31(\mathrm{TN})$ and $0.45(\mathrm{MK})$ in the indigenous pig breeds. The genotypes frequencies obtained in ME, TN and MC breeds were in Hardy-Weinberg equilibrium, while those for MK, YV and LV breeds were not.

\section{Discussion}

Sequencing results for intron 2 of the $H-F A B P$ gene from four indigenous pig breeds showed more than $99 \%$ identity with the reference sequence. Interestingly, a novel restriction site for the $M s p$ I at position $1556 \mathrm{bp}$ was detected for the first time in three Vietnamese indigenous pig breeds that are maintained in their original environments, whereas in exotic breeds only one MspI site has yet been detected. This mutation created a second MspI recognition site in the RFLP fragment, resulting in four alleles in the indigenous breeds. The novel restriction site for the $M s p I$ may be important for future genetic improvement.

As shown in Table 3 (A, B), a higher frequency of allele $A$ and allele $D$ at the $M s p$ I and HaeII RFLP sites was observed in indigenous pig breeds, with favourable alleles $a$ and $d$ present at low frequencies at $M s p I$ and HaeII sites. In the exotic breeds, the favourable allele $d$ frequency at HaeII site was higher ( $P$ $<0.01)$ than those in the indigenous pig breeds. Investigating the MspI and HaeIII polymorphisms of HFABP gene, Pang et al. (2006) revealed that the frequencies of allele $A$ (MspI-RFLP) and allele D (HaeIII-RFLP) in the Landrace breed were 0.912 and 0.328 , respectively. Meanwhile, the Chinese native pig breeds had the $A$ and $D$ allele only at MspI- and HaeIII-RFLP sites. The values of IMF content in European and Chinese breeds are considerably different, although they have the same genotype (Pang et al., 2006).

Intramuscular fat content depends on genotypes and breeds (Fisher, 1994). Association analysis revealed that the $H-F A B P$ alleles affected the IMF content significantly. This effect of $0.36 \%$ IMF among the homozygous genotypes is high, considering the overall mean of $1.84 \%$ IMF in the Meishan crossbred population (Gerbens et al., 1999). In the Chinese local pig breeds, the IMF content ordered by $H$-FABP genotypes was $H H>H h>h h, D D<D d<d d$ and $A A<A a<a a$. Fat deposition in adipocytes was higher in the $H H$, $d d$ and $a a$ genotypes than in others (Wei-Jun et al., 2006). In Polish native Złotnicka Spotted pigs, the meat with genotype $h h$ was marked by a higher intramuscular fat content $(2.64 \%)$ compared with the $H H$ group (1.99\%); $P \leq 0.05$ (Hanna et al., 2010). Besides the $H$-FABP gene, 29 genes are associated with the IMF content (Switonski et al., 2010). There are two possible ways of improving IMF content: enhancing favourable alleles and crossbreeding. Pig breeds of Vietnam have traditionally been selected for adaptation to a diet that is poor in protein content as well as to local ecologies. The indigenous pig breeds have a high rating for overall palatability and tenderness, and are thus said to have good meat quality. The meat of local pigs is low in moisture, and has low cooking losses and good flavour (Xuan et al., 1995). Our analysis showed that the IMF content in the Tap $\mathrm{Na}$ breed is significantly higher than in exotic breeds and ranges from $3.9 \%$ to $4.6 \%$ (data not shown). Such selection has driven an accumulation of new mutations with favourable phenotypic effects, as well as the development of alleles and haplotypes that differ from exotic breeds. The marker MspI-RFLP at T1556C position can be used to track the genetic materials in hybrids. The values of PIC at the MspI and HaeII RFLP sites in indigenous breeds are very low; this means that local pig breeds lack polymorphism at these sites.

Oedema disease and post-weaning diarrhoea in piglets are caused by enterotoxins (ETEC) produced by $E$. coli $\mathrm{F} 18$, which colonize the surface of the small intestine. The FUT1 gene has been identified as a candidate gene for controlling the expression of the ETEC F18 receptor. Animals of genotype $A A$ at the FUT1 locus are resistant and those of genotype $A B$ and $B B$ are susceptible to adhesion of F18ab E. coli bacteria (Meijerink et al., 1997). Luo et al. (2010) revealed a relationship between the FUT1M307 genotypes and the F18ab adhesion phenotypes. All individuals of genotype $A A$ were non-adhesive to both F18ab and F18ac. Meanwhile, all individuals of genotype $G G$ or $G A$ were adhesive to F18ab. In this study only the indigenous pig breeds possessed the susceptible genotypes $(G G, G A)$. The resistant genotype $A A$ was found only in exotic breeds. The favourable allele $A$ of $F U T 1$ gene in the exotic breeds was higher $(P<0.01)$ than those of indigenous pig breeds. Investigating the FUT1 polymorphism in some Chinese and Western pig breeds, Bao et al. (2008) also revealed that only Western pig breeds had the resistant genotype $A A$, while the Asian wild pig and the Chinese native pig breeds had only susceptible genotypes ( $G G$ and $G A$ ). It was inferred that oedema and post-weaning diarrhoea have close relationships with the growth rate and the halothane linkage group (HAL) on porcine chromosome 6 (Vögeli et al., 1996). Over a long period, pig 
breeds of Vietnam have traditionally been selected for adaptation to a diet poor in protein content and to local ecologies. The selection pressure on the growth rate in indigenous native pig breeds has been weak and their growth rate is generally low. This may be why most indigenous pig breeds lack genetic factors that provide resistance to ETEC F18 bacteria. Meanwhile, exotic pig breeds have been influenced by highintensity selection for a high lean growth rate for a long time. These effects of selection could have caused a high frequency of resistant allele $A$ in exotic breeds. The heterozygosity of $F U T 1$ gene was higher $(P<0.01)$ in the exotic pig breeds than in the Vietnamese indigenous breeds. The high heterozygosity of FUT1 genes in exotic breeds may be impacted by selective processes on favourable allele.

The BPI gene encodes a neutrophil protein with elimination functions against multiple gram-negative bacteria. The alleles of BPI gene are associated with several innate immune defence parameters, which are critical for control of and recovery from infection, and include fever and numbers of immune cells before and after infection. A pig with a $G$ allele at position 103 of exon 4 in the BPI gene has an increased probability of showing disease resistance after a challenge with Salmonella cholerasuis than a pig with an $A$ at this position (Tuggle et al., 2006). Our results showed that the genetic polymorphisms of the BPI locus were detected only in four indigenous pig breeds that possessed three different genotypes, while only the exotic pig breeds presented the resistant $G G$ genotype. The resistant allele $G$ of $B P I$ gene in the exotic breeds was significantly $(P<0.01)$ higher than in the indigenous pig breeds. Among the indigenous pig breeds, the frequency of allele $G$ was higher in TN than in the remaining breeds. This could explain why TN is said to be more resistant to certain diseases than other indigenous breeds. Consistent with our results, Tuggle et al., (2006) showed that the allele $G$ (AvaII digestion) was observed with a frequency of $100 \%$ in Yorkshire, Hampshire, Duroc, Landrace, Large White and wild boar. In Meishan pigs, allele $G$ was detected with a frequency of $31.3 \%$. The BPI gene is located on pig chromosome 17 and close to the lipopolysaccharide binding protein gene $(L B P)$ and phospholipid transfer protein gene (PLTP) (Shi \& Tuggle, 2001). These findings will be helpful in identifying candidate genes in these QTL regions related to immune competence and disease resistance in pigs. The higher frequency of the resistant allele $G$ in exotic breeds could be the result of selection and keeping them under controlled mating in a station. The pigs with the favourable allele will be chosen to produce more mature offspring than those without them, correspondingly, the frequency of favourable allele are increased. The AvaII polymorphic site of BPI gene was found in all indigenous breeds whereas in exotic breeds this locus was monomorphic. The high level of polymorphisms at the BPI locus in indigenous pig breeds can be explained by them being maintained in their original environments and less controlled mating.

The results reported here describes the genetic polymorphism of three candidate genes associated with meat quality and disease resistance in four Vietnamese indigenous and two Vietnamese exotic pig breeds. It is interesting that the average levels of heterozygosity of candidate genes $H-F A B P, F U T 1$ were higher in the exotic pig breeds than in the indigenous breeds. These results were contrary to those obtained by microsatellite analysis, where the expected heterozygosity in the Vietnamese indigenous breeds was higher than those in the European breeds (Thuy et al., 2006). The frequencies of the favourable alleles for $H$-FABP, FUT1 and BPI genes are higher in the exotic breeds than in the indigenous breeds. Among the indigenous pig breeds, TN showed a higher frequency of the resistant allele $G$ at $B P I$ gene than in the remaining breeds. Further research on the association between candidate genes and both meat quality and biodiversity of Vietnamese pigs is recommended.

\section{Conclusions}

The favourable alleles of $H-F A B P, F U T 1$ and $B P I$ gene in the exotic breeds are significantly higher than those of indigenous pig breeds. The T1556C mutation at intron 2 of $H$-FABP gene found in some indigenous pig breeds may be used as MspI-RFLP marker to identify or track the source of genetic material in IMF improvement by crossbreeding. The Tap Na pig may be a source of resistant alleles to the local ecology owing to a high frequency of resistant allele $G$ of BPI gene.

\section{Acknowledgment}

This study was supported by a grant of the Research Order No 106.02.165.09 of the Vietnam's National Foundation for Science and Technology Development (NAFOSTED). 


\section{References}

Bao, W.B., Wu, S.L., Musa, H.H., Zhu, G.Q. \& Chen, G.H., 2008. Genetic variation at the alpha-1fucosyltransferase (FUT1) gene in Asian wild boar and Chinese and Western commercial pig breeds. J. Anim. Breed. Genet. 125, 427-430.

Bostein, D., White, R.L., Skolnick, M. \& Davis, R.W., 1980. Construction of a genetic linkage map in man using restriction fragment length polymorphisms. Am. J. Hum. Genet. 32, 314-331.

Cameron, N.D. \& Enser, M.B., 1991. Fatty acid composition of lipid in longissimus dorsi muscle of Duroc and British Landrace pigs and its relationship with eating quality. Meat Sci. 29, 295-307.

Duc, N.V., Tuyen, G.H. \& Tuan, D.C., 2004. Basic characteristics of the local Tap Na pig breed in Thong Nong, Cao Bang. National Institute of Animal Husbandry - 50 years of development.

Eikelenboom, G., Howing-Bolink, A.H. \& Van der Wal, P.G., 1996. The eating quality of pork. 2. The influence of intramuscular fat. Fleischwirt 76, 517-518.

Elsbach, P. \& Weiss, J., 1998. Role of the bactericidal/permeability-increasing protein in host defence. Curr. Opin. Immunol. 10, 45-49.

Fischer, K., 1994. Zur Topographie des intramuskulaeren Fettgehaltes bei Rind und Schwein. Mitleitungsblatt der Bundesanstalt fuer Fleischforschung, Kulmbach 33, 112-120. (in German).

Gao, S.Z. \& Zhao, S.M., 2009. Physiology, affecting factors and strategies for control of pig meat intramuscular fat. Recent Patents on Food, Nutrition \& Agriculture 1, 59-74.

Gerbens, F., Van Erp, A.J., Harders, F.L., Verburg, F.J., Meuwissen, T.H.E., Veerkamp, J.H. \& te Pas, M.F.W., 1999. Effect of genetic variants of heart fatty acid-binding protein gene on intramuscular fat and performance traits in pigs. J. Anim. Sci. 77, 846-852.

Gerbens, F., de Koning, D.J., Harders, F.L., Meuwissen, T.H.E, Janess, L.L., Groenen, M.A., Veerkamp, J.H., Van Arendonk, J.A. \& te Pas, M.F., 2000. Effect of adipocyte and heart fatty acid-binding protein genes on intramuscular fat and backfat content in Meishan crossbred pigs. J. Anim. Sci. 78, $552-559$.

Gerbens, F., Verburg, F.J., Van Moerkerk, H.T., Engel, B., Buist, W., Veerkamp, J.H. \& te Pas, M.F., 2001. Association of the heart and adipocyte fatty acid-binding protein gene expression with intramuscular fat content in pigs. J. Anim. Sci. 79, 347-354.

Hai, L.T., 1996. Social features and the development of swine production in Vietnam. ACIAR Proc. 68, $186-189$.

Hanna, J., Natalia, S., Wojciech, K., Maria, B. \& Anna, Z., 2010. The effect of H-FABP gene polymorphism on carcass and meat quality in the Polish native Zlotnicka spotted pig. Journal of Central European Agriculture 11 (4), 459-464.

Hollings, P.E. \& Gray, P.W., 1994. EcoRI and BglII polymorphisms at the BPI-locus. Hum. Mol. Genet. 3, 389.

Hubacek, J.A., Stuber, F., Frohlich, D., Book, M., Wetegrove, S., Ritter, M., Rothe, G. \& Schmitz, G., 2001. Gene variants of the bactericidal/permeability increasing protein and lipopolysaccharide binding protein in sepsis patients: gender-specific genetic predisposition to sepsis. Crit. Care. Med. 29, 557-561.

Huy, V.S., Ly, L.V. \& Giao, H.K., 1996. Performance of exotic pig breeds raised in a breeding enterprise in Thanh Hoa province. Agricultural Publishing House, Results of Technical and Scientific Studies on Animal Husbandry, 1994-1995, 24.

Janss, L.L., de Koning, D.J., Rattubk, P., Van Arendonk, J.A. \& Brascamp, E.W., 1999. Detection of quantitative traits loci for bacfat thickness and intramuscular fat content in pig. Genetics 152, 1679-1690.

Lalitha, S., 2000. Primer 5. Biotech. Sofw. Internet. Rep. 1, 270-272.

Levy, O., Martin, S., Eichenwald, E., Ganz, T., Valore, E., Carroll, S.F., Lee, K., Goldmann, D. \& Thome, G.M., 1999. Impaired innate immunity in the newborn: newborn neutrophils are deficient in bactericidal/permeability-increasing protein. Pediatrics 104, 1327-1333.

Luo, Y., Qiu, X., Li, H. \& Zhang, Q., 2010. Association between the polymorphism in FUT1 Gene and the resistance to PWD and ED in three pig breeds. Asian-Aust. J. Anim. Sci. 23, 1268-1275.

Meijerink, E., Fries, R., Vogeli, P., Masabanda, J., Wigger, G., Stricker, C., Neuenschwander, S., Bertschinger, H.U. \& Stranzinger, G., 1997. Two alpha(1,2) fucosyltransferase genes on porcine 
chromosome 6q11 are closely linked to the blood group inhibitor (S) and Escherichia coli F18 receptor (ECF18R) loci. Mamm. Genome 8, 736-741.

Michaels, R.D., Whipp, S.C. \& Rothschild, M.F., 1994. Resistance of Chinese Meishan, Fengjing, and Minzhu pigs to the K88ac+ strain of Escherichia coli. Am. J. Vet. Res. 55, 333-338.

Molenat, M. \& Thong, T.T., 1991. La production porcine au Viet Nam et son amélioration. Wrld Anim. Rev. 68, 26-36. (in French).

Nei, M., 1978. Estimation of average heterozygosity and genetic distance from a small number of individuals. Genetics 89, 583-590.

Pang, W.J., Bai, L. \& Yang, G., 2006. Relationship among H-FABP gene polymorphism, intramuscular fat content, and adipocyte lipid droplet content in main pig breeds with different genotypes in Western China. Acta Genetica Sinica 33 (6), 515-524.

Sambrook, J., Fritsch, E.F. \& Maniatis, T., 1999. Molecular Cloning: A Laboratory Manual (2rd ed). Cold Spring Harbor Laboratory Press, New York, USA.

Shi, X.W. \& Tuggle, C.K., 2001. Rapid communication: genetic linkage and physical mapping of the porcine phospholipid transfer protein (PLTP) gene. J. Anim. Sci. 79, 1633-1634.

Switonski, M., Stachowiak, M., Cieslak, J., Bartz, M. \& Grzes, M., 2010. Genetics of fat tissue accumulation in pig: a comparative approach. J. AAp. Genet. 51 (2), 153-168.

Thien, N., Van, P.T., Le, P.N., Doanh, P.H., Nghi, N., Quac, N.K. \& Hot, V.T., 1996. Improvement of productivity and meat quality of pigs in the Red River Delta region by crossbreeding. ACIAR Proc. 86-89.

Thuy, N.T., Melchinger-Wild, E., Kuss, A.W., Cuong, N.V., Bartensclager, H. \& Geldermann, H., 2006. Comparison of Vietnamese and European pig breeds using microsatellites. J. Anim. Sci. 84, 2601-2608.

Tuggle, C.K., Stabel, T.J., Shi, X. \& Mellencamp, M.A., 2006. Genetic markers for improved disease resistance in animals (BPI). Patent Application Publication.

Veerkamp, J.H., Peeters, R.A. \& Maatman, R.G., 1991. Structural and functional features of different types of cytoplasmic fatty acid binding protein. Biophys. Acta 1081, 1-24.

Vögeli, P., Bertschinger, H.U., Stamm, M., Stricker, C., Hagger, C., Fries, R., Rapacz, J. \& Stranzinger, G., 1996. Genes specifying receptors for F18 fimbriated Escherichia coli, causing edema disease and post-weaning diarrhea in pigs, map to chromosome 6. Anim. Genet. 27, 321-328.

Wei-Jun, P., Liang, B. \& Gong-She, Y., 2006. Relationship among H-FABP gene polymorphism, intramuscular fat content, and adipocyte lipid droplet content in main pig breeds with different genotypes in Western China. Acta Genetica Sinica 33 (12), 1053-1140.

Xuan, V.T., Hai, L.T. \& Loc, C.B., 1995. Research priorities for improving animal production by agroecological zone in Vietnam. IRRI (eds), Global Agenda for Livestock Research, Proceedings of the Consultation for the South-East Asia region IRRI, Phillipines, 216-231. 